UDC 821.162.1-14.09 Franko I.

https://doi.org/10.18485/ms_zmss.2020.97.15

\author{
Andrzej Borkowski \\ Uniwersytet Przyrodniczo-Humanistyczny w Siedlcach \\ Wydzial Nauk Humanistycznych \\ andrzej.borkowski@uph.edu.pl \\ Andrzej Borkowski \\ Siedlce University of Natural Sciences and Humanities \\ Faculty of Humanities \\ andrzej.borkowski@uph.edu.pl
}

\title{
POLSKOJĘZYCZNA POEZJA IWANA FRANKI \\ WOBEC LITERATURY I KULTURY POLSKIEJ XVII I XVIII W. (KONTEKSTY I PARALELE)
}

\section{POLISH LANGUAGE POETRY BY IVAN FRANKO IN RELATION TO THE 17TH AND 18TH CENTURY POLISH LITERATURE AND CULTURE (CONTEXTS AND PARALLELS)}

Prezentowany artykuł stanowi próbę interpretacji polskojęzycznej twórczości poetyckiej Iwana Franki w kontekście literatury i kultury polskiej XVII i XVIII w. Bliższy ogląd utworów ukraińskiego autora wskazuje nie tylko na jego związki z twórczością polskich romantyków (Adam Mickiewicz, Juliusz Słowacki), ale też ujawnia powiązania z literaturą polskiego baroku (Jan Andrzej Morsztyn, Szymon Zimorowic) oraz oświecenia (Franciszek Karpiński, Stanisław Trembecki). W świetle analiz widać, że polska literatura romantyczna jest wykorzystywana przez Frankę w wierszach satyrycznych, natomiast w utworach miłosnych ujawniają się echa inspiracji literaturą barokową i oświeceniową.

Słowa kluczowe: Iwan Franko, poezja polska, Galicja, barok, oświecenie.

The article is an attempt to interpret Polish language poetic works of Ivan Franko in the context of Polish literature in the 17th and 18th centuries. The analysis presents not only connections between the works of the Ukrainian author and works of Polish Romantic writers (Adam Mickiewicz, Juliusz Słowacki), but also reveals the links with Polish literature of the Baroque (Jan Andrzej Morsztyn, Szymon Zimorowic) and the Enlightenment (Franciszek Karpiński, Stanisław Trembecki). It seems that Polish Romantic literature is used by Franko in his satiric poems, whereas noticeable echoes of the inspiration from the Baroque and Enlightenment literature can be found in his romantic works.

Key words: Ivan Franko, Polish poetry, Galicia (Eastern Europe), Baroque, Age of Enlightenment. 
Artykuł jest próbą odczytania polskojęzycznej twórczości lirycznej Iwana Franki w szerszym kontekście tradycji literatury polskiej, także w odniesieniu do jej okresu przedrozbiorowego. Do tego typu dociekań mogą skłaniać po pierwsze doświadczenia edukacyjne autora Lelum i Polelum, w tym znajomość polskich tekstów literackich, również tych, które znajdowały się wówczas w kanonie szkolnym, po drugie wszechstronne zainteresowania ukraińskiego pisarza twórczością Polaków, czemu dawał wyraz niejednokrotnie w esejach poświęconych literaturze i kulturze polskiej (Franko 1979).

W niniejszym szkicu szczególną uwagę zwraca się na tradycję przedromantyczną, do której - jak się wydaje — badacze twórczości Franki przywiązywali nieco mniejszą wagę. Florian Nieuważny za Marianem Jakóbcem stwierdził, że w utworach miłosnych ukraińskiego poety pobrzmiewa „[...] typowa frazeologia polskich romantyków" (Franko 2008: CXXVI). Zdaniem tych badaczy wpływy romantyczne, z czym należy się w znacznej mierze zgodzić, widać również w wierszach satyrycznych Franki. Trudno odmówić tym opiniom trafności, zwłaszcza, że w eseju „Poeta zdrady” (Franko 1979: 60-75) ukraiński myśliciel pisał o tym, że ukończył polskie gimnazjum, gdzie niezwykle ważnym elementem edukacji literackiej było komentowanie twórczości Adama Mickiewicza:

„[...] wiersze jego znajdowały się w wypisach szkolnych, musieliśmy dokładnie znać życiorys tego poety i treść jego najwybitniejszych dzieł, rocznica jego urodzin była uroczyście obchodzona przez młodzież szkolną — słowem przyzwyczajono nas czcić Mickiewicza jako jednego z największych herosów ducha i jego słowa, jako emanację największego geniuszu, uważać za święte". (Franko 1979: 60)

Przekorne usposobienie Franki oraz jego intelektualna ciekawość sprawiały, że rzucał on wyzwanie utartym schematom interpretacyjnym poezji polskiego wieszcza za co spotkała go już kara w czasach szkolnych - jak napisał: ,[...] za swą heretycką egzegezę dostałem dobrze po uszach od dyrektora" (Franko 1979: 61; Hrycak 2010: 92). Doświadczenia Franki w tym zakresie jako żywo przypominają genialnie sparodiowaną przez Witolda Gombrowicza w powieści Ferdydurke lekcję romantyzmu polskiego. Obaj autorzy zwracali uwagę zarówno na słabości kształcenia literackiego, jak też swoiście bałwochwalczą wizję literatury i kultury polskiej prezentowaną przez gimnazjalnych nauczycieli. $Z$ drugiej strony m.in. te doświadczenia szkolne wykrzywiły obraz literatury polskiej na tyle, że, jak pisał Edward Kasperski, dokonując gruntownej analizy oraz krytyki tekstu Franki na temat Mickiewicza, ukraiński autor ,zaplątał się w sidłach etnocentryzmu i nie był w stanie się z nich wydobyć" (Kasperski 2017: 589)

Czytanie Franki w tym naświetleniu przedromantycznym nie może przekreślać wyżej przywołanych objaśnień filologicznych oraz komentarzy samego autora, lecz jest próbą wytyczenia kolejnych ścieżek interpretacyjnych, które mogą ujawnić nieco inne podglebie intelektualno-artystyczne tej liryki. 
Do takiej lektury zachęca chociażby wystąpienie Franki „Wzajemny stosunek literatury polskiej i ruskiej" (Franko 1979: 291-294). W tym referacie wygłoszonym na Zjeździe Literatów i Dziennikarz Polskich (1894) Franko może pochwalić się głębszą wiedzą na temat historii literatury polskiej oraz jej związków z Rusią. Franko wskazał tu na pisarzy tej miary, jak Sebastian F. Klonowic i jego poemat Roxolania, twórczość Wespazjana Kochowskiego, Szymona Szymonowica, sielankopisarstwo braci Zimorowiców. Przypomniał też Wojne chocimska Wacława Potockiego czy Panoszę Bartosza Paprockiego. Poza tym warto zauważyć, że Franko włączył się w dyskusję na temat najstarszej pieśni polskiej — „Bogurodzicy” (Franko 1979: 279-290). Ponadto w kontekście kulturowych związków polsko-rusińskich pamiętał również o znanych dziełach oświeceniowych autorów, a zwłaszcza Sofijówce Stanisława Trembeckiego, Wojnie chocimskiej Ignacego Krasickiego czy też twórczości, pochodzącego z Pokucia, Franciszka Karpińskiego (Borkowski 2018: 94).

W tym wystąpieniu więcej miejsca poświęcił Iwan Franko literaturze bliższej sobie czasowo, a zwłaszcza romantyzmowi polskiemu, koncentrując się na twórcach tej miary, jak Adam Mickiewicz, Juliusz Słowacki czy Seweryn Goszczyński. Poza tym wyraził zainteresowanie twórczością pozytywistów (Bolesław Prus, Maria Konopnicka), jak też dorobkiem młodopolan (Jan Kasprowicz, Zenon Przesmycki [Miriam], Stanisław Przybyszewski. Nie zmienia to jednak faktu, że ukraiński pisarz i myśliciel widział literaturę - co jest godne podkreślenia - w szerokiej perspektywie czasowej, nie tracąc $\mathrm{z}$ horyzontu zjawisk dawniejszych.

Do głębszych poszukiwań na temat inspiracji, zależności i źródeł poezji Franki skłania też kształt gatunkowy jego niektórych wierszy oraz język jego wypowiedzi literackiej. Warto w tym miejscu podkreślić, że poeta ucieka się niekiedy do formy „sonetu”, który upowszechnił się zwłaszcza w literaturze polskiego baroku, a potem w okresie romantyzmu, czego przykładem są utwory Mikołaja Sępa-Szarzyńskiego, Jana Andrzeja Morsztyna, a następnie Adama Mickiewicza i poetów nieodległych czasowo ukraińskiemu pisarzowi. Trzeba też przyznać, że samemu autorowi Pana Tadeusza bliska była poezja oświeceniowa, w tym Stanisław Trembecki i jego frywolna, rokokowa twórczość (Seweryn 1997, Borowy 1978).

Do tradycji barokowej nawiązuje poeta pośrednio w wierszu „O złe i dobre, które w sercu noszę" (Franko 2008: 257-258). Utwór odsyła do wydarzeń pozaliterackich i jest poetyckim echem miłości poety do Olgi Roszkiewicz. Liryk skomponowany jest z serii retorycznych pytań i antytez: „Szczęściem twym — bóle, a śmiercią — rozkosze; / Gdyś ty nie miłość, jakież imię twoje? (Franko 2008: 257). Ten ostatni wers pobrzmiewa niczym pieśniowy refren. To rozwiązanie formalne zbliża ten tekst do twórczości ludowej. Warto zauważyć, że tego rodzaju ukształtowanie brzmieniowe wierszy było znamienne dla utworów, które wpisywały się dawniej w bogatą twórczość o charakterze sielankowym. Przykładem niech będzie poezja znanych France Zimorowiców, chociażby wiersz „Siedmnasta: Marantula” (ze zbioru Roksolanki), gdzie wy- 
stępują takie refreniczne zawołania na końcu każdej ze strof: „Przyjmiże, mój namilszy kochany, / Ode mnie ten wianeczek różany” (Zimorowic 1983: 51-52).

Poza tym wyraźnie rysuje się w twórczości lirycznej Franki znane w baroku upodobanie do paradoksów i kontrastów, które dobrze widać w sonetach Jana Andrzeja Morsztyna. Ponadto ukraiński autor posługuje się często wykorzystywaną w poezji XVIII w. metaforyką „,miłosnej wojny”, którą odnaleźć można chociażby w twórczości Stanisława Trembeckiego. Jego znakomity tekst okolicznościowy „Epitalame Dorantowi i Klimenie, czyli Miłość złączona” ukazuje ją jako swoistą batalię: „Najwięcej umysł zakłóca spokojny, / Toczenie krwawej i nieznanej wojny: / Bez sekundanta, bez tarczy, bez broni, / Cóż ją od razu srogiego zasłoni?! (Trembecki 1965: 48) Ten sposób obrazowania uczuć zjawia się również we wspomnianym wyżej sonecie Iwana Franki: „Czemu ustawnie jestem niespokojny? / Nie mam spokoju — nie prowadząc wojny? (Franko 2008: 258). Opisany w wierszu niepokój, a zarazem gotowość do podjęcia walki, przypomina duchowe skupienie żołnierza w czasie śmiertelnej konfrontacji. Na marginesie rodzi się pytanie o istotę tak ukazywanej miłości. Pokazywanie jej w bitewnym sztafażu nie wydaje się tylko efektownym chwytem literackim, ale wskazuje na sposób myślenia o niej w kategoriach niejako militarnych: „zdobywania” czy „podboju” (notabene taka konceptualizacja miłości zjawia się niekiedy w lirykach Rainera Marii Rilkego). Ponadto w wierszu pojawiają się uwagi o miłości, która przypomina jakieś śmiertelne odrętwienie — jak napisze Franko: „Wznoszę się w niebo, a martwy na ziemi" (Franko 2008: 258). Ta konceptualizacja miłosnych uniesień sytuuje ten tekst się niedaleko sonetu Jana Andrzeja Morsztyna Do trupa: „Leżysz zabity i jam też zabity, / Ty — strzałą śmierci, ja — strzałą miłości” (Morsztyn 1971: 105).

Jak się wydaje najpełniej kunszt poetycki autora Mojżesza w kontekście literackiej gry z barokową tradycją ujawnia się w wierszu „Do C[eliny] Ż [urowskiej]”: „Tak muszla, gdy w jej wnętrze ostry kamyk wleci, / Zamyka się, w swe ciało wciska grot raniący, / Najlepsze swoje soki wkoło niego sączy, / Aż zginie, lecz z niej perła na twej szyi świeci" (Franko 2008: 267). Warto w tym miejscu dodać, że ten koncept poetycki zakorzenia się również w samej genezie określenia „barok”, który jako termin jubilerski funkcjonował już w XVI w. Jak pisał Janusz Pelc ,[...] barok najprawdopodobniej wywodzi się od portugalskiego słowa „barocco”, określającego perłę o kształtach nieregularnych, niezwykłych" (Pelc 1993: 5). Miłość w powyższej strofie jawi się jako bolesny proces, który przypomina obronną reakcję małży na obce ciało. Cierpienie podmiotu lirycznego, z racji przemożnego uczucia, przypomina właśnie narodziny perły. Jawi się ona jako drogocenne trofeum, które zdobi szyję bohaterki.

Warto podkreślić, że kochliwe usposobienie Iwana Franki odsyła pośrednio do innej ważnej postaci w literaturze polskiego oświecenia - Franciszka Karpińskiego, którego wielorakie związki z Rusią ujawniają się na poziomie zarówno biograficznym (urodził się w Hołoskowie na Pokuciu), jak też tematycznym jego twórczości (opisy kresowej przyrody). Miłosne wiersze ukra- 
ińskiego pisarza - podobnie jak w przypadku polskiego poety sentymentalnego - odznaczają się dość wysokimi rejestrami „czułości” oraz zgodą na nieszczęsny los zakochanego, jak w wierszu „Do Józi Dzwonkowskiej”: „Niech nigdy myśl Twa z czynem nie będzie w rozterce / I niech dla godniejszego zapłonie Twe serce"! (Franko 2008: 263). Poza tym warto podkreślić, że obu autorów zbliżają do siebie owe „miłości”, czyli konkretne kobiety; w wierszach Karpińskiego adresatkami poetyckich westchnień były Justyny.

Oprócz poezji miłosnej na uwagę badawczą zasługuje również, bogata w pierwiastki ironii, twórczość satyryczna Iwana Franki. Odsłania ona bujny temperament polemiczny i usposobienie humorystyczne ukraińskiego autora. Ostrze satyry kieruje poeta także w stronę Polaków, którzy jawią się w tych tekstach jako osobowości niejednoznaczne moralnie. Twórczość tego typu można umieścić w kręgu tzw. „literatury stosowanej”. Termin ten, autorstwa Stefanii Skwarczyńskiej, notabene pracownika naukowego Uniwersytetu Jana Kazimierza we Lwowie, sytuuje tego rodzaju pisarstwo w dziale szeroko rozumianej „literatury dydaktycznej” z wyrazistymi inklinacjami moralizatorskimi (Skwarczyńska 1931: 17).

Niezależnie od klasyfikacji teoretycznych należy stwierdzić, że Franko obdarzony był dużym talentem satyrycznym, wskazując na pewne wady społeczeństwa polskiego. Dobrym przykładem jest wiersz „My lubimy Rusinów” (Franko 2008: 260-261), w którym ukazano nie tyle lekceważący stosunek Polaków do innych nacji, ale konformizm poszczególnych środowisk oraz nazbyt widoczne rachuby polityczne. Utwór odsłania również ekonomiczne i kulturowe napięcia, które ujawniają się między wsią i dworem, Rusinami i, przywiązanymi do dawnej tradycji szlachecko-ziemiańskiej, Polakami. Widać to wyraźnie w finale wiersza: „Lecz kto chciałby dla Rusi/Naszą ukrócić wolność [...]/ Tworzyć literaturę/I gazety wydawać [...]/ Ten jest Moskal, szyzmatyk, / Hajdamackie skaranie, / Apostata, zaprzaniec, / Zdrajca kraju, mospanie!" (Franko 2008: 261). Ukraiński autor piętnował tu politykę elit, która prowadziła do - jak wolno sądzić — kulturowej i edukacyjnej dominacji jednej tylko grupy ludności. Narzucanie polskiego kodu kulturowego (język i literatura) skutkowało, rzecz jasna, sprzeciwem intelektualistów ukraińskich. Jak zaznaczyła Katarzyna Glinianowicz: „Polski przekaz kresowy wywoływał sprzeciw ruskich pisarzy galicyjskich. Nie zgadzali się oni na dalszy ucisk ze strony polskości generujący upośledzenie ich rodzimej kultury oraz polonizację ich elity" (Glinianowicz 2015: 32).

W kontekście tytułowego zagadnienia bardziej interesujące wydają się jednak nawiązania przez Frankę do kultury Polski przedrozbiorowej. Zwrot „mospanie” zarezerwowany był w okresie I Rzeczpospolitej dla ludzi o wyższym statusie społecznym, czyli szeroko rozumianej szlachty. Franko pokazuje tym samym, manifestowana zapewne w relacjach towarzyskich, swoista ,wsobność" Polaków, która przejawiała się w postaci określonych rytuałów czy też zwrotów grzecznościowych znamiennych dla tej właśnie grupy ludności. Ponadto poeta wskazał na przywiązanie tzw. Lachów do wyznania katolickiego. 
Terminy „schizmatyk” czy „apostata” odsyłają do religijnych napięć między Kościołem Zachodnim i Wschodnim. Użycie tych pojęć przez Frankę w tekście sugeruje, że świadomość zadrażnień i różnic religijno-kulturowych, osadzona zresztą głęboko w historii obu narodów, miała wówczas żywy rezonans, odzwierciedlający się jasno na poziomie aluzji poetyckich. Ponadto dyskurs literacki Franki wskazuje na żywe podglebie dawnych konfliktów. „Hajdamackie skaranie" to określenie, które przywołuje zbrojne bunty ludności (chłopi, Kozacy) zamieszkującej Ukrainę w wieku XVIII (Franko 2008: 261).

W satyrycznej twórczości Franko przypomina też polskich pisarzy, jak chociażby Tomasz Kajetan Węgierski, znakomity poeta osiemnastego stulecia, który za swe satyryczne uwagi wyrażane w poezji został pozbawiony wolności. Jest to owszem tylko daleka analogia, jednakże to doświadczenie więzienia zbliża w znaczący sposób tych twórców do siebie, zwłaszcza, że obaj trafili tam za szerzenie poglądów dla władzy niewygodnych czy wręcz niebezpiecznych. Już w inicjalnych fragmentach tekstu „My lubimy Rusinów” Franko wskazuje na swoistą mentalność kolonizatora, jaką ujawniali — w jego opinii - Polacy: „My lubimy Rusinów, / Ich zwyczaje prastare, /Plemię ruskie, co kocha/ Swoich panów, swą wiarę" (Franko 2008: 260). W kolejnych wersach poeta ironicznie wskazywał na ,interesowną" i udawaną w istocie miłość Polaków do Rusinów, którzy darzą o tyle sympatią ten naród, o ile widzą w tym ekonomiczną korzyść oraz ochronę swych przywilejów.

Równie ciekawie jawi się tekst „Pieśń o uobywatelnieniu Żydów”, który przypomina w swej strukturze dramat. Podział głosów w utworze („głośno” oraz „,po cichu”) odsłania wyraźny rozdźwięk i polityczną hipokryzję ówczesnych elit i środowisk (zapewne - w opinii Franki - znaczącej ich części), które w kształtowaniu relacji polsko-żydowskich kierowały się doraźnym zyskiem. Wypowiedziane „na głos” słowa: „Ha, widzicie, i w Warszawie/ Burza zbiera się nad wami! / Czas wam, Żydzi albo zginąć, Albo zostać Polakami” (Franko 2008: 259) — skontrastowane zostały z ,szeptem”: „Wielki kredyt, mały procent, - / To ustaną wszelkie waśnie; / Lecz gdy tego nie zechcecie,/Niech was jasny piorun trzaśnie!” (Franko 2008: 259). Franko napiętnował tu swoiście merkantylny stosunek jakiejś części elit polskich do ludności wyznania mojżeszowego. W świetle wiersza zgromadzone przez nią fundusze mają posłużyć Polakom do realizacji określonych celów politycznych: „Płaćcie datki niezliczone/Na „potrzeby narodowe”! (Franko 2008: 259). W zamian za to oferuje się Żydom jedynie pozorne dołączenie do wspólnoty narodowej: „Wprawdzie zawsze Żyd jest Żydem,/Chociaż i w kontuszu hula” (Franko 2008: 259).

W innym wierszu „Pobożne wzdychanie do teki ministerialnej JWP Euzebiusza Czerkawskiego" Iwan Franko genialnie naśladuje poważną tonację hymnu czy ody w odniesieniu do sytuacji, która nie mieści się w zakresie tematycznym owych znanych literaturze z dawien dawna gatunków. Tym samy poeta uzyskuje pożądany efekt komiczny: „Wśród ciemnej nocy na ruinach marzeń / Śpiewam — rozbitek zasad i wydarzeń, / A głos mój płynie z wiatrem 
daleko — / Do ciebie, teko!" (Franko 2008: 263). Liryczna lamentacja bohatera odnosi się do niespełnionych marzeń i zamierzeń politycznych bohatera. Ministerialna teka jawi się w utworze niczym mityczna Kolchida, złote runo, którego wartość jest godna najwyższej ofiary, co oczywiście daje tu efekt swoiście groteskowy. W wierszu Franki można doszukać się pewnej analogii z hymnem „Smutno mi Boże” Juliusza Słowackiego, co ujawnia się na poziomie prozodycznym: „Smutno mi, Boże! — Dla mnie na zachodzie/Rozlałeś tęczę blasków promienistą; / Przede mną gasisz w lazurowej wodzie/ Gwiazdę ognistą... / Choć mi tak niebo Ty złocisz i morze, / Smutno mi Boże!”' (Słowacki 2005: 119). Przywołajmy teraz fragment utworu Franki: „Bo jeśli nie mam ziomków zaufania,/ To jakże państwo zaufać mi może?/Głos mi się urwał od płaczu i łkania,/Zlituj się, Boże!” (Franko 2008: 265). Szerzej o wpływach tradycji romantycznej na twórczość Iwana Franki pisał m.in. wspomniany już Marian Jakóbiec (Franko 2008: CXXVI).

Liryczna twórczość polskojęzyczna Iwana Franki jest niewątpliwie frapującym zjawiskiem literackim. Otwiera się ona - jak próbowano tu dowieść - na bogate tradycje literatury polskiej, szczególnie te przedromantyczne. Warto podkreślić, że nieprzypadkowo twórczość romantyków jest wykorzystywana przez ukraińskiego autora w utworach o nachyleniu satyrycznym. Swiadczy to poniekąd o zużywaniu się tej tradycji, jej starzeniu się. W utworach miłosnych można dostrzec echa głębszych, przedromantycznych inspiracji.

\section{BIBLIOGRAFIA}

Borkowski Andrzej. „Symbolika drzewa (lasu) w twórczości Franciszka Karpińskiego”. Філологиччний часойис 12/2 (2018): 93-100.

Borowy Wacław. O poezji polskiej w wieku XVIII. Warszawa 1978.

Franko Iwan. O literaturze polskiej. Oprac. Mikołaj Kuplowski. Kraków 1979.

Franko Iwan. Wybór poezji. Oprac. Florian Nieuważny. Wrocław 2008.

Glinianowicz Katarzyna. Z cienia polskości. Ukraińska proza galicyjska przełomu XIX i XX wieku. Kraków 2015.

Hrycak Jarosław. Prorok we własnym kraju. Iwan Franko i jego Ukraina (1586-1886). Warszawa 2010.

Kasperski Edward. „Dyskurs zdrady. Iwan Franko a Adam Mickiewicz”. Київські йолоністиичні cūuydï. XXIX (2017): 562-591.

Morsztyn Jan Andrzej. Utwory zebrane. Oprac. Leszek Kukulski. Warszawa 1971.

Pelc Janusz. Barok - epoka przeciwieństw. Warszawa 1993.

Skwarczyńska Stefania. „O pojęcie literatury stosowanej”. Pamiętnik Literacki 28/1-4 (1931): $1-24$.

Słowacki Juliusz. Wiersze. Oprac. Jacek Brzozowski i Zbigniew Przychodniak. Poznań 2005.

Trembecki Stanisław. Wiersze wybrane. Oprac. Juliusz W. Gomulicki. Warszawa 1965.

Seweryn Dariusz. Jak tam zaszedłeś? Mickiewicz w szkole klasycznej. Lublin 1997.

Zimorowic Szymon. Roksolanki. Oprac. Ludwika Ślękowa. Wrocław 1983.

Радишевський Ростислав. „Іван Франко в інтертексті польського романтизму”. Київські

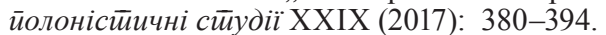

Radishevs'kii Rostislav. „Ivan Franko v interteksti pol'skogo romantizmu”. Kiivs'ki polonisichni studii XXIX (2017): 380-394. 
Анджеј Борковски

\author{
ПОЕЗИЈА ИВАНА ФРАНКА НА ПОљСКОМ ЈЕЗИКУ \\ У КОНТЕКСТУ ПОЉСКЕ КЬИЖЕВНОСТИ И КУЛТУРЕ XVII И XVIII ВЕКА \\ (КОНТЕКСТ И ПАРАЛЕЛЕ)
}

\begin{abstract}
Резиме
Овај чланак представља покушај интерпретације песничког стваралаштва Ивана Франка на пољском језику у контексту пољске књижевности и културе XVII и XVIII века. Проучавањем дела украјинског писца откривају се не само његове веза са стваралаштвом пољских романтичара (Адам Мицкјевич, Јулиуш Словацки), већ и везе са књижевношћу пољског барока (Јан Анджеј Морштин, Шимон Зиморовиц), те просветитељства (Франћишек Каприњски, Станислав Трембецки). Анализа показује да је пољску романтичарску књижевност Франко користио у сатиричним песмама, док се у онима са љубавном тематиком осећа утицај барокне и просветитељске књижевности.
\end{abstract}

Кључне речи: Иван Франко, пољска поезија, Галиција, барок, просветитељство. 